\title{
Herbage intake by steers grazing in a natural grassland with predominance of Andropogon lateralis Nees managed under different canopy heights
}

\section{Ricardo Biasiolo ${ }^{1^{*}(\mathbb{D})}$ Pablo Giliard Zanella ${ }^{1}$ Cássio Felipe Lopes $^{1}$ (i) Artur Martins Barbosa $^{1}$ (i) Tiago Celso Baldissera ${ }^{2}$ (i) Cassiano Eduardo Pinto ${ }^{2}$ (i) Fabio Cervo Garagorry ${ }^{3}$ (i) Henrique Mendonça Nunes Ribeiro-Filho ${ }^{1}$ (i)}

${ }^{1}$ Centro de Ciências Agroveterinárias, Universidade do Estado de Santa Catarina, 88520-000, Lages, SC, Brasil. E-mail: rb.biasiolo@edu.udesc.br. ${ }^{*}$ Corresponding author.

${ }^{2}$ Empresa de Pesquisa Agropecuária e Extensão Rural de Santa Catarina, Estação Experimental de Lages, Lages, SC, Brasil. ${ }^{3}$ Embrapa Pecuária Sul, Bagé, RS, Brasil.

ABSTRACT: The animal performance on pasture is directly correlated to canopy structure since this influences the herbage consumption. This study was evaluated the effects of four pre-grazing canopy heights (12, 20, 28 and $36 \mathrm{~cm}$ ) of Andropogon lateralis Ness on herbage intake and feeding behavior of steers in a natural grassland under intermittent stocking management, using the same proportion of defoliation (40\% reduction in pre-grazing height, i.e., post-grazing heights of 7.2, 12.0, 16.8 and $21.6 \mathrm{~cm}$ ). The experiment was conducted on a total area of $14,000 \mathrm{~m}^{2}$, divided into sixteen paddocks of $875 \mathrm{~m}^{2}$. Thirty-two steers were used, divided into uniform pairs according to the live weight (LW) at the start of the experiment $(244 \pm 23.0 \mathrm{~kg})$. Each paddock was subdivided into three plots of identical area; the first two plots were used for the adaptation period and the third for the assessment period. A randomized block design was used with four replicates and two assessment periods. Herbage mass and neutral detergent fiber content increased linearly $(P<0,001)$ with the increase of pre-grazing canopy heights. In contrast, was not affected by treatments, with mean values of $75 \mathrm{~g} / \mathrm{kg}$ of dry matter (DM) in the upper stratum and $83 \mathrm{~g} / \mathrm{kg}$ of DM in lower stratum. The herbage intake was similar between treatments $(P=0.255)$, averaging $1.78 \% \mathrm{LW}$. Grazing time increased linearly in the upper stratum and decreased linearly in the lower stratum with increasing pre-grazing canopy heights. Total time spent grazing, ruminating, and idling did not differ between treatments, with means of 52.6\%, 23.0\%, and 24.2\%, respectively. Pre-grazing canopy heights treatments, based on the predominant species A. lateralis, did not affect the daily herbage intake of steers.

Key words: intermittent grazing, feeding behavior, pasture quality, canopy structure.

Consumo de forragem por novilhos em área de pastagem natural com predomínio de Andropogon lateralis Ness manejada em diferentes alturas

RESUMO: O desempenho de animais em pastejo possui direta correlação com a estrutura do dossel forrageiro, uma vez que este influencia o consumo. Objetivou-se mensurar o consumo e o comportamento ingestivo de novilhos em pastagem natural "palha grossa", manejada sob lotação intermitente, com diferentes alturas de pré pastejo (12, 20, 28, 36 cm), aferidas na espécie predominante Andropogon lateralis Ness, com severidade de desfolha de 40\%. O experimento foi conduzido em uma área total de $14.000 \mathrm{~m}^{2}$, dividida em dezesseis piquetes de $875 \mathrm{~m}^{2}$. Foram utilizados 32 novilhos, divididos em lotes uniformes conforme o peso vivo no início do experimento (244 $\pm 23,0 \mathrm{~kg}$ ). Cada piquete foi subdividido em três parcelas de igual área, sendo utilizadas as duas primeiras para o periodo de adaptação e a terceira para o período de avaliação. O delineamento experimental foi de blocos ao acaso, com quatro repetições e dois periodos de avaliação. As metas de altura em pré-pastejo foram alcançadas em todos os tratamentos. A massa de forragem aumentou linearmente $(P<0,001)$ com o aumento das alturas de pré-pastejo. Os teores de fibra em detergente neutro aumentaram linearmente $(P<0,001)$ com o aumento das alturas de manejo, enquanto a proteina bruta foi semelhante $(P=0,107)$ entre os tratamentos tendo valores médios de $75 \mathrm{~g} / \mathrm{kg}$ de matéria seca $(M S)$ no estrato superior e de 83 $\mathrm{g} / \mathrm{kg} \mathrm{MS}$ no estrato inferior. O consumo de forragem foi similar entre tratamentos $(P=0,255)$, com média de 1,78\% do peso vivo. A porcentagem de tempo que os animais pastejaram no estrato superior aumentou e a porcentagem no estrato inferior diminuiu linearmente $(P<0,001)$ com o aumento das alturas de manejo. As porcentagens do tempo total destinado ao pastejo, ruminação ou ócio não diferiram entre tratamentos ( $P$ $>0,05)$, com médias de 52,6\%, 23,0\% e 24,2\%, respectivamente. Alturas de pré pastejo entre 12 e $36 \mathrm{~cm}$, baseadas na espécie predominante Andropogon lateralis Ness, não interferiram no consumo diário de matéria seca de novilhos em pastejo.

Palavras - chave: pastejo intermitente, comportamento ingestivo, qualidade do pasto, estrutura do pasto.

\section{INTRODUCTION}

Natural grasslands can be characterized as natural pastoral biosystems and their exploitation using livestock represents one of the best forms of sustainable land use (TILMAN et al., 1996; CARVALHO \& BATELLO, 2009). When grazed, these environments tend to create a canopy structure 
with a double vertical stratum, with prostrate growth species prevailing in the lower stratum. This stratum has more plants preferred by domestic herbivores, while the upper stratum has grass species that form tussocks, which are less preferred by herbivores (MCNAUGHTON \& BANYIKWA 1995; QUADROS \& PILLAR 2001; PINTO et al., 2007; TRINDADE et al., 2012).

Andropogon lateralis Ness (Poaceae) is one of the most important species of the upper stratum of natural grasslands from southern Brazil (GOMES et al., 1990; BOLDRINI, 2002). This is a perennial tussock-forming species, greenish-gray color, and feathery inflorescences (ARAÚJO, 1971). Moreover, $A$. lateralisis is highly rustic and resistant to frosts, fire, trampling, and grazing (HERVÉ \& VALLS, 1980; TRINDADE \& ROCHA, 2002).

The grazing intensity on this double stratum mosaic has a direct cause and effect relationship between herbivory and species diversity, as natural grasslands managed with high intensity grazing select species with canopy structures close to the soil that are adapted to overgrazing (HALFORD et al. 2008). In contrast, the exclusion of or moderate and light intensity grazing promotes the prevalence of tussockforming grass species (BOLDRINI \& EGGERS 1996, QUADROS \& PILLAR 2001; TRINDADE et al., 2012), which can affect the feeding behavior and daily herbage intake.

Herbage consumption is a major factor affecting animal performance (MERTENS, 1994; MOORE, 1997, CARVALHO 2005). In fact, herbage consumption and nutrient digestibility account for approximately $60-90 \%$ and $10-40 \%$ of animal performance, respectively (MERTENS, 1994). Moreover, herbage consumption in grazing animals is influenced by nutritional and non-nutritional factors (POPPI et al., 1987). The nutritional factors are related to digestibility, chemical composition, and metabolic factors of the herbage, while the non-nutritional factors are related to environmental elements, such as ease of harvesting and retention of herbage (HODGSON, 1990).

In a pastoral environment, the responses of both plants and animals are influenced and determined by variations and conditions of the canopy structure (HODGSON \& DA SILVA, 2000). Canopy structure is defined as the distribution and spatial arrangement of plant aerial components and the most used variables to measure canopy structures are height, herbage mass, herbage density, and leaf: stem ratio (LACA \& LEMAIRE, 2000). These structural characteristics determine grazing efficiency, as it influences total nutrient intake (STOBBS, 1973) and herbage intake (HODGSON, 1990).

The canopy height is one of the main factors influencing pasture structure, as it affects the amount of available herbage and its accessibility to the animals (PENNING et al., 2004; COSGROVE, 1997). Bite depth and volume is positively correlated with canopy height and negatively correlated with pasture density (UNGAR et al., 1991; LACA et al., 1992; GORDON and LASCANO, 1993). However, bite depth cannot compensate for low density of herbage above a certain height and due to the dispersion of leaves in the upper strata. In a natural grassland from biome Pampa, canopy height above $11.4 \mathrm{~cm}$, cause a decrease in bite mass: and consequently, in herbage intake in heifers (GONÇALVES, 2009c).

To provide height management recommendations, this study measured the effect of four different pre-grazing canopy heights of $A$. lateralis on the daily herbage intake by steers in an intermittent stocking grazing. Additionally, we tested the hypothesis that excessively low $(12 \mathrm{~cm})$ or excessively high $(36 \mathrm{~cm})$ pre-grazing heights of $A$. lateralis reduces the daily herbage intake compared with that of intermediate heights $(20$ and $28 \mathrm{~cm})$.

\section{MATERIALS AND METHODS}

\section{Experiment condition}

The experiment was conducted in Lages, $\mathrm{SC}$, Brazil $\left(50.18^{\circ} \mathrm{W}, 27.47^{\circ} \mathrm{S} ; 920 \mathrm{~m}\right.$ altitude) at the Experimental Station of Lages (Estação Experimental de Lages - EEL) that belongs to the Company of Agricultural Research and Rural Extension of Santa Catarina (Empresa de Pesquisa Agropecuária e Extensão Rural de Santa Catarina - Epagri). The climate is $\mathrm{Cfb}$ according to the Koppen classification; humid mesothermal with a mild summer. The experimental area is composed of a natural grassland whose physiognomy is characterized by "palha grossa" with predominance of the species A. lateralis (GOMES et al., 1990). The experimental area has been managed since August 2015 with pre-grazing canopy height treatments of $12,20,28$, and $36 \mathrm{~cm}$ measured in the predominant species, and a same proportion of defoliation ( $40 \%$ reduction in pre-grazing height, i.e., post-grazing heights of 7.2, 12.0, 16.8 and $21.6 \mathrm{~cm}$ ).

The experiment was designed in randomized blocks, with four replicates, and an area of $875 \mathrm{~m}^{2}$ per experimental unit. The experimental units were subdivided into three equivalent areas, with two subdivisions used for the animals' adaptation period and the third period for the assessment and sampling. 


\section{Animal husbandry and experimental period}

Thirty-two Hereford and Braford crossbred steers were separated into 16 uniform pairs according to the live weight $(243.8 \pm 23 \mathrm{~kg} \mathrm{LW})$ at the start of the experiment. Water and minerals were made available ad libitum for animals in the experimental units. The study was conducted in two periods, the first from $11 / 12 / 2017$ to $12 / 22 / 2017$, and the second from $01 / 22 / 2018$ to $03 / 03 / 2018$.

\section{Animal measurements}

Daily herbage intake was measured through the fecal nitrogen $(\mathrm{N})$ in daily excretion, using a specific equation for natural grasslands from southern Brazil (KOZLOSKI et al., 2018), where consumption of organic matter (OM) (g/kg LW) $=1.1+101.2 \times \mathrm{N}$ excreted in the feces $(\mathrm{g} / \mathrm{kg} \mathrm{LW})$ $\left(\mathrm{R}^{2}=0.83\right)$. The $\mathrm{N}$ excreted in the feces was calculated as the product of the daily production of feces and the fecal concentration of N. Daily production of feces was determined, using feces collection bags, for four days (from the $9^{\text {th }}$ to the $12^{\text {th }}$ day) for treatments 12,20 , and $28 \mathrm{~cm}$, and five days (from the $11^{\text {th }}$ to the $15^{\text {th }}$ day) for $36 \mathrm{~cm}$ treatment in each experimental period. The interval between experimental periods was necessary to reach defoliation severity of the pre-grazing canopy height by $40 \%$. The bags were emptied twice a day, at 07:00 and 19:00 h, and the fecal contents were weighed. Then, the feces were homogenized, and a sample $(\sim 200 \mathrm{~g})$ was collected and dried in an oven with forced ventilation at $55^{\circ} \mathrm{C}$ for $72 \mathrm{~h}$. After drying, the samples were grinded through a $1-\mathrm{mm}$ sieve and stored until the fecal $\mathrm{N}$ content analysis.

The feeding behavior was assessed using visual observation (PENNING\& RUTTER, 2004) every $5 \mathrm{~min}$ for twelve uninterrupted hours (07:00 to 19:00 $\mathrm{h}$ ) on the $1^{\text {st }}$ and $3^{\text {rd }}$ day of grazing in the sampling paddock. The following animal behavioral parameters were recorded: grazing in the upper stratum, grazing in the lower stratum, rumination, and idleness.

The first sub-model of Pampa Corte model, a computational decision-making tool for livestock systems, was used to compare the measured values. This model simulates food intake and digestion, predicting daily consumption based on the amount of neutral detergent fiber (NDF), acid detergent fiber (ADF), crude protein (CP), degradation kinetics $(k)$, and digestibility of natural grassland (SILVEIRA, 2002).

\section{Pasture measurements}

The herbage samples were collected once a day during the assessment period through hand- plucking to determine the bromatological composition of the herbage in each stratum (JOHNSON, 1978). The canopy height was measured using a sward stick (BARTHRAM, 1985) at 50 points per experimental subunit, both before and after grazing, with 25 measurements in the upper stratum of $A$. lateralis and 25 in the lower stratum. The herbage mass (HM) was determined by visual estimation through standard comparison, calibrated with double sampling, grouping the two strata (HAYDOCK; SHAW, 1975). Eight visual estimates of HM and two cuts close to the ground were performed using a $0.25 \mathrm{~m}^{2}$ frame per subdivision in each experimental unit. For each visual estimate, the biomass within each frame was estimated, and pasture samples were collected and dried in an oven with forced ventilation at $55^{\circ} \mathrm{C}$ for 72 $\mathrm{h}$. The vertical distribution of species and morphological components in the canopy before grazing were quantified according to the inclined point quadrat method (WILSON, 1960). It was sampled a total of 400 points per experimental unit, recorded the species (Andropogon lateralis or others), morphological component (leaf, stem, or dead material), and corresponding height for each point.

\section{Laboratory analyses}

The herbage dry matter (DM) content was determined by drying samples in an oven at $105^{\circ} \mathrm{C}$ for $24 \mathrm{~h}$. The ash content was measured by combustion in a muffle furnace at $550{ }^{\circ} \mathrm{C}$ for $4 \mathrm{~h}$, and the $\mathrm{OM}$ content was calculated by mass difference. The total $\mathrm{N}$ content of the herbage and feces samples was determined by combustion according to the method of Dumas No. 968.06 (AOAC, 1997) using the N LECO $^{\circledR}$ FP528 analyzer (LC, Leco Corporation, Saint Joseph, EUA). The CP of the herbage samples was calculated by the amount of $\mathrm{N} \times 6.25$. The NDF concentration was analyzed according to MERTENS (2002), and the ADF concentration was quantified according to method No. 973.18 of the AOAC (1997), both using the ANKOM A200 I equipment (ANKOM Technology, Macedon NY, USA).

The herbage samples were analyzed using the in vitro digestion/gases technique (MAURICIO et al., 1999). Each sample $(0.5 \mathrm{~g})$ was weighed in duplicate and incubated in $160 \mathrm{~mL}$ glass flasks with $50 \mathrm{~mL}$ of buffered rumen fluid (4:1 buffer solution/ rumen fluid ratio) (THEODOROU et al., 1994). The rumen fluid was obtained from rumen fistula in cattle fed exclusively with herbage. The samples were kept for $96 \mathrm{~h}$ under constant agitation in a Dubnoff bath (MARCONI MA-092) at $39^{\circ} \mathrm{C}$. The volume of produced gases was measured at $6,12,18,24,30$, 
36, 42, 48, 60, 72, and $96 \mathrm{~h}$ after incubation using a pressure transducer. The gas production curves over the incubation time were adjusted to the dual logistic model of SCHOFIELD et. al., (1994) to estimate the kinetic parameters of degradation.

\section{Statistical analysis}

Data were analyzed by analysis of variance (ANOVA) using the package lmr4 (BATES et al., 2015) of the statistical program R (R CORE TEAM, 2017), with analysis of the normality of residues and homogeneity of variances. The blocks, pre-grazing canopy heights (treatment), and assessment periods were fixed effects, and the experimental units (combination of block with treatment) were randomized effect. Post ANOVA, linear and quadratic effects were tested by orthogonal polynomial contrasts.

\section{RESULTS}

\section{Canopy structure}

The pre-grazing canopy heights of the upper stratum were reached according to the goals foreseen for the corresponding treatments, while the heights of the lower stratum increased linearly as the pre-grazing canopy heights increased $(\mathrm{P}<0.001)$ (Table 1). The proportion of defoliation for postgrazing canopy heights of the upper stratum were $49.4 \%, 41.7 \%, 44.8 \%$, and $42.4 \%$ for treatments $12,20,28$, and $36 \mathrm{~cm}$, respectively. Therefore, the $\mathrm{HM}$ and the herbage allowance in the pre-grazing increased linearly $(\mathrm{P}<0.05)$ as a result of the increase of the pre-grazing canopy height of the upper stratum (Table 2).

\section{Herbage intake}

DM herbage intake was similar for all treatments with a mean of $4.6 \mathrm{~kg} \mathrm{DM} /$ day (Table
2). When expressed as a percentage of live weight, the mean was $1.78 \%$. The OM digestibility showed a quadratic response $(\mathrm{P}<0.05)$ as the pre-grazing canopy height increased. The herbage intake estimated with the Pampa Corte model, based on the bromatological composition of the upper and lower strata, decreased linearly with the increase in pregrazing canopy heights (Table 2).

\section{Herbage quality and feeding behavior}

In the upper stratum, the DM content showed a quadratic response $(\mathrm{P}<0.05)$ with the increase in pre-grazing canopy heights (Table $3)$. The OM, NDF, and ADF contents increased linearly $(\mathrm{P}<0.05)$ with the increase in pre-grazing canopy heights of the upper stratum. The CP content (mean of $75 \mathrm{~g} / \mathrm{kg}$ of DM) was not affected by the increase in the pre-grazing canopy height. The $k$ values decreased linearly $(\mathrm{P}<0.05)$ as the pre-grazing canopy height increased.

The DM content in the lower stratum showed a quadratic response $(\mathrm{P}<0.05)$ with the increase of the pre-grazing canopy height, while the CP contents (mean of $83 \mathrm{~g} / \mathrm{kg}$ of DM) were similar between treatments (Table 3). The OM, NDF, and ADF contents increased linearly $(\mathrm{P}<0.05)$ as a function of the pre-grazing treatments. The $k$ values decreased linearly $(\mathrm{P}<0.05)$ with the increase of pregrazing canopy height.

While grazing time in the upper stratum increased linearly with the increase of canopy height, the opposite trend was observed in the lower stratum (Table 4). The total grazing time (mean of $51.8 \%$ ), rumination time, and idle time did not differ between treatments.

\section{Vertical canopy structure}

The treatments influenced the distribution of species and morphological components in the

Table 1- Canopy height of upper and lower strata of a natural grassland at pre- and post-grazing. SD $=$ standard deviation.

\begin{tabular}{|c|c|c|c|c|c|c|c|c|}
\hline \multirow[b]{2}{*}{ Item } & \multicolumn{6}{|c|}{----------------Height (cm)-------------- } & \multicolumn{2}{|c|}{-----------P value--------- } \\
\hline & 12 & 20 & 28 & 36 & $\mathrm{SD}$ & ANOVA & Linear & Quadrat \\
\hline \multicolumn{9}{|c|}{ 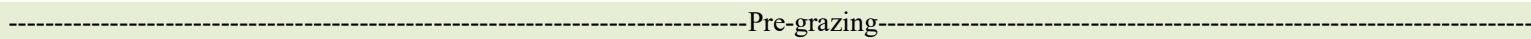 } \\
\hline Upper stratum $(\mathrm{cm})$ & 11.9 & 19.9 & 27.9 & 35.8 & 1.599 & $<.001$ & $<.001$ & 0.590 \\
\hline Lower stratum $(\mathrm{cm})$ & 4.5 & 6.2 & 8.8 & 10.8 & 0.456 & $<.001$ & $<.001$ & 0.680 \\
\hline \multicolumn{9}{|c|}{ 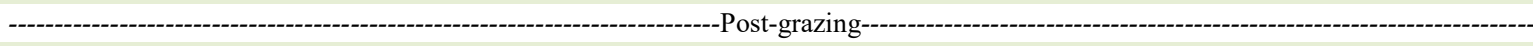 } \\
\hline Upper stratum $(\mathrm{cm})$ & 6.0 & 11.6 & 15.4 & 20.6 & 0.968 & $<.001$ & $<.001$ & 0.767 \\
\hline Lower stratum $(\mathrm{cm})$ & 2.6 & 3.1 & 4.2 & 5.7 & 0.250 & $<.001$ & $<.001$ & 0.034 \\
\hline
\end{tabular}

Ciência Rural, v.51, n.10, 2021. 
Table 2 - Herbage mass and allowance, consumption, and digestibility in a natural grassland managed at different canopy heights. SD = standard deviation.

\begin{tabular}{|c|c|c|c|c|c|c|c|c|}
\hline & \multicolumn{6}{|c|}{--------------------Height (cm)------------------ } & \multicolumn{2}{|c|}{-----------P value----------. } \\
\hline Item & 12 & 20 & 28 & 36 & $\mathrm{SD}$ & ANOVA & Linear & Quadrat \\
\hline \multicolumn{9}{|c|}{ 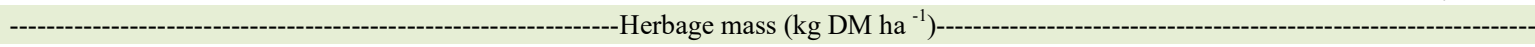 } \\
\hline Pre-grazing & 3479 & 4619 & 7135 & 9896 & 212.0 & $<.001$ & $<.001$ & 0.404 \\
\hline \multicolumn{9}{|c|}{ - } \\
\hline & 5.0 & 6.9 & 10.2 & 11.3 & 0.28 & $<.001$ & $<.001$ & 0.340 \\
\hline \multicolumn{9}{|c|}{ 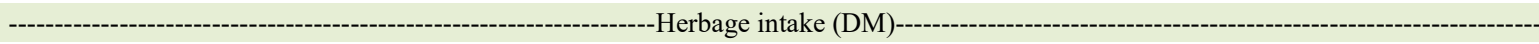 } \\
\hline $\mathrm{kg} \mathrm{DM} /$ day & 4.77 & 4.49 & 4.5 & 4.60 & 0.147 & 0.295 & - & - \\
\hline$\% \mathrm{LW}$ & 1.85 & 1.78 & 1.75 & 1.76 & 0.083 & 0.255 & - & - \\
\hline $\mathrm{dOM}^{1}$ & 52.6 & 50.2 & 46.9 & 49.3 & 0.912 & 0.032 & 0.501 & $<.001$ \\
\hline \multicolumn{9}{|c|}{--1 } \\
\hline Upper stratum & 1.76 & 1.6 & 1.53 & 1.55 & 0.003 & $<.001$ & $<.001$ & 0.562 \\
\hline Lower stratum & 1.71 & 1.64 & 1.58 & 1.57 & 0.001 & $<.001$ & $<.001$ & 0.321 \\
\hline
\end{tabular}

${ }^{1} \mathrm{OM}$ digestibility.

canopy $(\mathrm{P}<0.05)$ (Figure 1). There was a quadratic response $(\mathrm{P}<0.01)$ in the percentage of green leaves of A. lateralis with the pre-grazing height of $20 \mathrm{~cm}$ presenting the highest percentage of green leaves (47\%), followed by $12 \mathrm{~cm}(43 \%), 28 \mathrm{~cm}(42 \%)$, and 36 $\mathrm{cm}(39.6 \%)$. The percentage of green leaves of other species decreased linearly $(\mathrm{P}<0.01)$ with the increase of pre-grazing canopy heights, with mean values of $29 \%, 19 \%, 17 \%$, and $14 \%$ in heights of $12,20,28$, and $36 \mathrm{~cm}$, respectively. Pre-grazing canopy heights had a

Table 3 - Chemical composition and in vitro digestibility of herbage samples in the upper and lower stratum of a natural grassland managed at different canopy heights. SD = standard deviation.

\begin{tabular}{|c|c|c|c|c|c|c|c|c|}
\hline \multirow[b]{2}{*}{ Item } & \multicolumn{6}{|c|}{----------------Height (cm)----------------- } & \multicolumn{2}{|c|}{-------------P value-------------. } \\
\hline & 12 & 20 & 28 & 36 & SD & ANOVA & Linear & Quadrat \\
\hline \multicolumn{9}{|c|}{-----------------------------------------------------------------------Upper stratum--------------------------------------------------------------------------- } \\
\hline $\mathrm{DM}\left(\mathrm{g} \mathrm{kg}^{-1}\right)$ & 40.8 & 49.8 & 45.5 & 49.9 & 2.46 & 0.038 & 0.308 & 0.041 \\
\hline \multicolumn{9}{|c|}{ 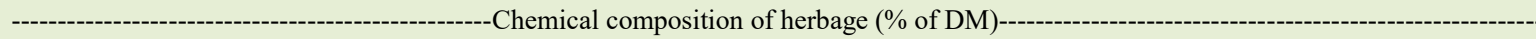 } \\
\hline $\mathrm{OM}$ & 94.5 & 95.6 & 96.0 & 96.2 & 0.42 & $<0.001$ & $<0.001$ & 0.004 \\
\hline $\mathrm{CP}$ & 8.2 & 7.5 & 7.0 & 7.4 & 0.36 & 0.107 & - & - \\
\hline $\mathrm{NDF}$ & 69.5 & 71.7 & 73.4 & 75.6 & 0.49 & $<0.001$ & $<0.001$ & 0.732 \\
\hline $\mathrm{ADF}$ & 35.2 & 35.9 & 36.5 & 39.2 & 0.46 & $<0.001$ & $<0.001$ & 0.036 \\
\hline $\mathrm{k}(\% / \mathrm{h})$ & 2.56 & 2.47 & 2.38 & 2.32 & 0.043 & 0.042 & 0.007 & 0.058 \\
\hline \multicolumn{9}{|c|}{ 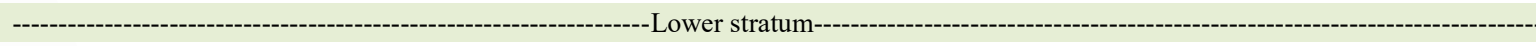 } \\
\hline $\mathrm{DM}\left(\mathrm{g} \mathrm{kg}^{-1}\right)$ & 38.6 & 49.2 & 46.1 & 49.1 & 2.79 & 0.033 & 0.045 & 0.014 \\
\hline \multicolumn{9}{|c|}{ - } \\
\hline $\mathrm{OM}$ & 94.0 & 94.5 & 94.8 & 95.1 & 0.24 & 0.011 & $<0.001$ & 0.053 \\
\hline $\mathrm{CP}$ & 8.7 & 8.2 & 8.1 & 8.2 & 0.47 & 0.077 & - & - \\
\hline NDF & 66.0 & 68.8 & 70.1 & 72.2 & 0.88 & 0.001 & $<0.001$ & 0.502 \\
\hline $\mathrm{ADF}$ & 31.8 & 33.7 & 35.0 & 36.5 & 0.53 & $<0.001$ & $<0.001$ & 0.571 \\
\hline $\mathrm{K}(\% / \mathrm{h})$ & 2.66 & 2.58 & 2.53 & 2.37 & 0.036 & $<0.001$ & $<0.001$ & 0.301 \\
\hline
\end{tabular}

$\mathrm{DM}=$ dry matter, $\mathrm{OM}=$ organic matter, $\mathrm{CP}=$ crude protein, $\mathrm{NDF}=$ neutral detergent fiber, $\mathrm{ADF}=$ acid detergent fiber, $k=$ degradation kinetics.

Ciência Rural, v.51, n.10, 2021. 
quadratic effect $(\mathrm{P}<0.01)$ on the percentage of stems of $A$. lateralis and other species, with values of 3.5 , 3.3, 4.0, and 7.5\% in A. lateralis and 5.8, 2, 2.2, and $2.3 \%$ in the other species in the $12,20,28$, and $36 \mathrm{~cm}$, respectively. There was a linear effect $(\mathrm{P}<0.01)$ on the percentage of dead material with the increase of the canopy heights, with mean values of $18,28,35$, and $37 \%$ for treatments $12,20,28$, and $36 \mathrm{~cm}$, respectively.

\section{DISCUSSION}

Effect of A. lateralis height on canopy herbage intake Our results rejected the hypothesis that extreme canopy heights (12 and $36 \mathrm{~cm}$ ) limit herbage intake and intermediate heights (20 and $28 \mathrm{~cm}$ ) optimize herbage intake. This hypothesis was based on results of canopy heights in different physiognomies of natural grasslands by GONÇALVES et al. (2009c) and TRINDADE et al., (2016). They showed that too low or very high canopy heights limited herbage intake due to structural limitations, such as proximity to the ground or stem elongation. Our results demonstrated that there were nutritional limitations for herbage intake in a natural "palha grossa" grassland with a higher proportion of A. lateralis, even at intermediate canopy heights. Furthermore, environmental aspects associated with canopy structure, flora composition, and grazing mechanisms may also have affected consumption.

The LW mean $(1.78 \%)$ of herbage intake was similar to the value estimated by the Pampa Corte model (SILVEIRA, 2002). This model considers as input nutrition-related variables: $\mathrm{CP}$, $\mathrm{NDF}, k$, and digestibility. The values estimated by the model were $1.63 \%$ of LW for the upper stratum and
$1.65 \%$ of LW for the lower stratum (Table 2). This model was developed to predict animal performance based on natural grasslands from southern Brazil, and the results of the present study showed that DM consumption above $2 \%$ of LW is unlikely to be achieved by steers grazing in a natural grassland with predominance of $A$. lateralis.

\section{Effect of the chemical composition of the pasture on herbage intake}

The mean NDF content reported in the present study $(70.6 \%)$ is close to that found by Silveira et al. (2005), who obtained $72.6 \%$ of NDF in the central region of Rio Grande do Sul, which also has $A$. lateralis as the predominant species. NDF is the main nutritional factor limiting consumption in animals ingesting herbage-based diets, since it is directly associated with rumen filling (VAN SOEST, 1965). García et al. (2007) indicated that, in addition to rumen filling, high NDF contents reduce digestibility and energy intake. According to Mertens (1994), dairy cows have a limited consumption of NDF content of 1.2 to $1.3 \%$ of their LW. Here, the NDF consumption estimated by the Pampa Corte model was $1.3 \%$ and $1.2 \%$ of LW in animals grazing in the upper and lower stratum, respectively.

The CP contents (\% DM) of $A$. lateralis (7.5\%) were closed to those reported by Santos et al., (2013), 6.4\%, in a study that assessed the nutritional value of the grasses of the pampa biome under grazing. Peripolli et al., (2011), who analyzed data compiled from digestibility experiments with different herbages, including natural grasslands, and found them a value of $7.8 \% \mathrm{CP}$. CP content has an important effect on consumption. In fact, $\mathrm{CP}$ values

Table 4 - Parameters of the feeding behavior of steers in a natural grassland managed at different canopy heights. SD $=$ standard deviation.

\begin{tabular}{|lcccccc}
\hline & & & & \\
\hline & & & & \\
\hline
\end{tabular}




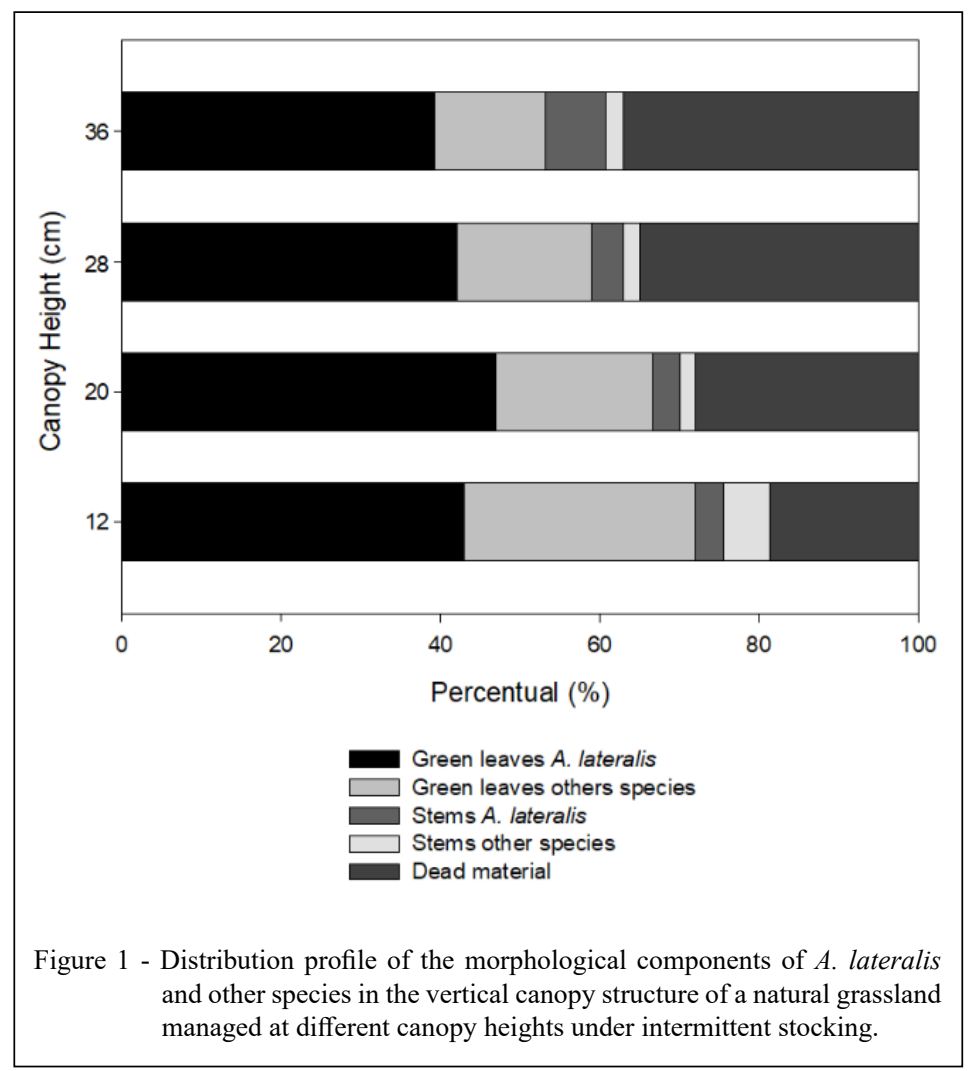

below $8 \%$ of the diet decreases fiber digestibility due to a low supply of ruminal $\mathrm{N}$ for cellulolytic bacteria (VAN SOEST, 1992). Cline et al. (2008) observed a linear decrease in the OM consumption accompanied by a linear decrease in the $\mathrm{CP}$ content for animals grazing in natural grassland in western North Dakota, which was mainly caused by a decrease in ruminal digestibility. Moreover, these authors obtained a consumption value of $1.52 \%$ of the animal LW when the $\mathrm{CP}$ was approximately $8.0 \%$ of DM, which is similar to that verified in our experiment.

\section{Effect of the canopy structure on herbage intake}

According to POPPI et al. (1987), the herbage intake by animals on pasture is directly related to canopy components, such as herbage mass and allowance and canopy height. According to HODGSON (1990), maximum consumption levels are reached with an herbage allowance of approximately two to three times the animal's needs. Thus, a daily supply of 10 to $12 \mathrm{~kg} \mathrm{DM} / 100 \mathrm{~kg} \mathrm{LW}$ allows the maximum individual performance of animals on pasture. These values are similar to those reported by Maraschin (1998) in a study that determined the optimal herbage allowance for natural pastures are between 11.5 and $13.5 \%$ of the animal's LW. However, the herbage allowance in this study was below than $11.5 \%$ in all treatments (Table 2). TRINDADE et al. (2016) studied the same physiognomy of natural pastures and obtained the highest daily herbage intake and nutrient consumption rates in natural grasslands under continuous grazing with an herbage allowance of $12.1 \%$ of LW and a consumption of $2.61 \%$ of LW. Barbieri et al. (2014) observed the same DM intake of $2.04 \%$ of LW in two herbage allowances of 14.7 and $9.7 \%$ of LW in a natural grassland under rotational grazing. The range of the herbage allowance and the DM intake were lower in our study compared with those reported by these authors.

The lower stratum heights may also have limited consumption, since they can be considered below the reference values suggested by other authors in order to maximize the rate of herbage intake. GONÇALVES et al. (2009b) tested the effect of four different pre-grazing canopy heights of a natural grassland on the intake rate of calves and concluded that the canopy height of $11.4 \mathrm{~cm}$

Ciência Rural, v.51, n.10, 2021. 
maximizes the consumption, while the canopy heights of 8 and $4 \mathrm{~cm}$ decreased consumption in $15 \%$ and $50 \%$, respectively. According to these authors, the observed decreased consumption is due to a reduction in the bite depth due to the difficulty of capturing the herbage, causing the animals to consume smaller amounts of herbage. These authors also observed a decrease in the consumption rate when the canopy heights were greater than $11.4 \mathrm{~cm}$. A possible explanation for this observation is that bite depth cannot compensate for low herbage density and the dispersion of leaves in the upper stratum of the canopy, causing a reduction in bite mass. Here, the height of the lower strata ranged from 4.5 to 10.8 $\mathrm{cm}$ across all treatments (Table 1), which may have limited consumption due to a decrease in bite depth. These results corroborated the study of Trindade et al. (2016) who observed a decrease in herbage intake of about $15 \%$ and $25 \%$ when the heights of lower stratum under continuous grazing ranged from 11.2 to $8.7 \mathrm{~cm}$ and from 11.2 to $4.8 \mathrm{~cm}$, respectively. In our study, only the $12 \mathrm{~cm}$ treatment showed a higher proportion of soil cover of the lower stratum, with a value similar to the reported by GONÇALVES et al. (2009c) and Trindade (2016). The proportion of the lower stratum was $58,40,33.4$, and $21.8 \%$ for treatments $12,20,28$, and $36 \mathrm{~cm}$, respectively (DELLA GIUSTINA JUNIOR et al. (2019). In addition, the lower stratum is mainly composed of herbage plants that are part of the cattle diet.

\section{Effect of canopy height on feeding behavior}

With the increase in canopy heights, the heterogeneity of the canopy structure increases, thus allowing species like $A$. lateralis to form tussocks in a higher proportion (CARVALHO \& BATELLO, 2009;) Furthermore, the fact that tussocks have more sparce leaves hinders herbage intake, since it becomes more difficult bite manipulation, resulting in a decrease in the bite mass, and, consequently, in DM intake (LACA et al., 1994; GORDON, 2000; BREMM, 2010).

The increase in canopy height elevated the $A$. lateralis structure, subjecting grazing animals to contrasting canopy structures in the pasture. Furthermore, the lower stratum became increasingly scarce, causing less selectivity to the preferred herbage in order to maintain the intake rate. Thus, the animals had to adjust their feeding behavior by increasing the grazing time in the upper stratum. This behavior corroborated the optimal foraging theory (PYKE, 1984), which predicts that the costs of obtaining food can modify food choices. The reduction in grazing time in the lower stratum was equivalent to the increase in grazing time in the upper stratum, as demonstrated by the similar percentage of grazing time during the period of observation of the animals. However, it cannot be concluded that there was an increase in the daily grazing time in any treatment, since the assessment was performed only during the day. An increase in the daily grazing time would indicate a greater difficulty of animals to graze. According to CARVALHO (2009), the grazing time is rarely less than six and more than 12 hours and is always concentrated in the early morning and late afternoon. However, the harder the foraging, the longer the grazing time.

\section{CONCLUSION}

Herbage intake by steers in natural grasslands predominated by $A$. lateralis is not affected by different pre-grazing canopy heights due to restrictions from herbage quality and structure with values of approximately $1.8 \%$ of LW.

\section{ACKNOWLEDGEMENTS}

This work was supported by Fundação de Amparo à Pesquisa e Inovação do Estado de Santa Catarina (FAPESC; Finance code TR 584 2019), and Conselho Nacional de Desenvolvimento Científico e Tecnológico (CNPq; NEXUS II, MCTI/CNPq n: 441396/2017-8).

\section{BIOETHICS AND BIOSSECURITY COMMITTEE APPROVAL}

We authors of the article entitled "Herbage intake by steers grazing in a natural grassland with predominance of Andropogon lateralis Nees managed under different canopy heights" declared, for all due purposes, the project that gave rise to the present data of the same has not been submitted for evaluation to the Ethics Committee of the "Santa Catarina State University (UDESC)", but we are aware of the content of the Brazilian resolutions of the National Council for Control of Animal Experimentation CONCEA "http://www.mct.gov.br/index.php/content/ view/310553.html" if it involves animals. Thus, the authors assume full responsibility for the presented data and are available for possible questions, should they be required by the competent authorities.

\section{DECLARTION OF CONFLICT OF INTEREST}

The authors declare no conflict of interest. The founding sponsors had no role in the design of the study; in the collection, analyses, or interpretation of data; in the writing of the manuscript, and in the decision to publish the results. 


\section{AUTHORS' CONTRIBUTIONS}

All authors contributed equally for the conception and writing of the manuscript. All authors critically revised the manuscript and approved of the final version.

\section{REFERENCES}

AOAC. Official methods of analysis of the Association of Official Analytical Chemists. 16 ed. Washington: W. Horwitz, 850 p, 1997. BARTHRAM, G. T. Experimental techniques: the HFRO sward stick. In: The Hill Farming Research Organization Biennial Report 1984/1985. Penicuik: HFRO, 1985. p.29-30.

BATES, D. et al. Fitting Linear Mixed-Effects Models Usinglme4. Journal Of Statistical Software, [S.L.], v.67, n.1, p.1-48, 10 jul. 2015. Foundation for Open Access Statistic. From: $<$ https://www. jstatsoft.org/article/view/v067i01>. Accessed: Mar. 23, 2019. doi: 10.18637/jss.v067.i01

BOLDRINI, I. I. Campos sulinos: caracterização e biodiversidade. In: ARAÚJO, E. A. et al. (ed.). Biodiversidade, conservação e uso sustentável da flora do Brasil. Recife: UFPe/Soc. Bot. do Brasil. 2002. p.95-97. Available from: <http://ecoqua.ecologia.ufrgs.br/ arquivos/Livros/CamposSulinos.pdf>. Accessed: Jun. 11, 2019.

BOLDRINI, I. I.; EGGERS, L. Vegetação campestre do sul do Brasil: dinâmica de espécies à exclusão do gado. Acta Botanica Brasilica, [S.L.], v. 10, n. 1, p. 37-50, jul. 1996. FapUNIFESP (SciELO). Available from: <https://www.scielo.br/scielo.php?pid=S0102$33061996000100004 \&$ script $=$ sci arttext $>$. Accessed: Dec. 10 2018. doi: 10.1590/s0102-33061996000100004

CARVALHO, P. C. F. 2005. O manejo da pastagem como gerador de ambientes pastoris adequados `a produção animal. In: C. G. S. Pedreira, J. C. Moura, S. C. Da Silva, and V. P. de Faria [EDS.]. Teoria e prática da produção animal em pastagens. Piracicaba, Brazil: Fealq. p.7-32. Available from: <http://www.ufrgs.br/gpep/ documents/capitulos/Ambientes $\% 20$ pastoris $\% 20$ adequados $\% 20$ $\%$ C $3 \%$ A $0 \% 20$ produ $\%$ C $3 \%$ A $7 \%$ C $3 \%$ A 3o\%2 0 animal $\% 20$ (Esalq\%202005) >.pdf>. Accessed: Nov. 12, 2019.

CARVAlHO, P. C. F.. Access to land, livestock production and ecosystem conservation in the Brazilian Campos biome: the natural grasslands dilemma. Livestock Science, [S.L.], v.120, n.12, p.158-162, jan. 2009. Elsevier. Available from: < https://www. sciencedirect.com/science/article/abs/pii/S1871141308001285>. Accessed: Aug. 16, 2019. doi: 10.1016/j.livsci.2008.04.012.

COSGROVE, G. P. Grazing behaviour and forage intake. In: International Symposium on Animal Production under grazing, 1997, Viçosa, MG. Anais...Viçosa, MG: UFV, 1997. p.59-80.

DELLA GIUSTINA JUNIOR, L. H. P. et al. Grazing height management does not change the persistence pathway of Andropogon lateralis in a natural pasture. Pesquisa Agropecuária Brasileira (ONLINE), v.54, p.1-8, may 2019. Available from: $<$ https://www.scielo.br/scielo.php?script $=$ sci arttext\&pid=S0100204X2019000104301>. Accessed: May, 10, 2021. doi: 10.1590/ s1678-3921.pab2019.v54.00405.

GOMES, K. E. et al. Zoneamento das pastagens naturais do planalto catarinense. In: Reunião do grupo técnico regional do cone sul em melhoramento e utilização dos recursos rurais das áreas tropical e subtropical. 11., Lages, 1990 Anais... Lages: Empasc, 1990. p.54-61,
GONÇALVES, E. N. et al. Plant-animal relationships in a heterogeneous pastoral environment: displacement patterns and feeding station use. In: Revista Brasileira de Zootecnia, v.38, p.2121-2126, 2009a. FapUNIFESP (SciELO). Available from: $<$ https://www.scielo.br/scielo.php?script $=$ sci_abstract\&pid $=$ S151635982009001100008\&lng=en\&nrm=iso $>$. Accessed: Jan. 20, 2019. doi: 10.1590/S1516-35982009001100008

GONÇALVES, E. N. et al. Plant-animal relationships in pastoral heterogeneous environments: defoliation and selectivity patterns. Revista Brasileira de Zootecnia, [S.L.], v.38, n.4, p.611-617, abr. 2009b. FapUNIFESP (SciELO). Available from: $\quad<$ https://www.scielo.br/scielo.php?script=sci_arttext\&pi $\mathrm{d}=\mathrm{S} 1516-35982009000400004>$. Accessed: Jan. 20. 2019. doi: 10.1590/s1516-35982009000400004.

GONÇALVES, E. N. et al. Plant-animal relationships in pastoral heterogeneous environment: process of herbage intake. In: Revista Brasileira de Zootecnia, v.38, p.1655-1662, 2009c. FapUNIFESP (SciELO). Available from: <https://www.scielo.br/scielo. php pid $=$ S1516-35982009000900003\&script $=$ sci abstract $>$. Accessed: Jan. 20. 2019. doi: 10.1590/S1516-35982009000900003.

HALFORD, M. et al. (2008). Long-term impact of cattle grazing on the botanical composition and the vegetation dynamic of the natural pastures of the Pampa biome (Southern Brazil). Rangeland Ecology and Management. (2008)

HAYDOCK, K. P.; SHAW, N. H. The comparitive yield method for estimating dry matter yield of pasture. Australian Journal of Experimental Agriculture and Animal Husbandry, v.15, p.663$670,1975$.

HERVÉ, A. M. B.; VALLS, J. F. M. O gênero Andropogon L. (Graminae) no Rio Grande do Sul. Anuário Técnico do Instituto de Pesquisas Zootécnicas "Francisco Osório", Porto Alegre, v. 7, p. 317-410, 1980.

HODGSON, J. Grazing Management: Science into Practice. New York: John Wiley; Longman Scientific and Technical, 1990, 200 p.

HODGSON, J.; DA SILVA, S.C. Sustainability of grazing systems: goals, concepts and methods. In: LEMAIRE, G.; HODGSON, J.; MORAES, A.; CARVALHO, P.C.F.; NABINGER, C. (Eds.) Grassland ecophysiology and grazing ecology. CABI Publishing, CAB International, Wallingford, Oxon OX10 8DE, UK, 2000. p.1-14

KOZLOSKI, G. V. et al. Faecal N excretion as an approach for estimating organic matter intake by free-ranging sheep and cattle. The Journal of Agricultural Science, [s.1.], v. 156, n. 3, p.443449, abr. 2018. Cambridge University Press (CUP). Accessed: ago 23, 2019 doi:10.1017/S0021859618000412

LACA, E. A. et al. Effects of sward height and bulk density on bite dimensions of cattle grazing homogeneous swards. Grass and Forage Science, [S.L.], v.47, n.1, p.91-102, mar. 1992. Wiley. Available from: <https://onlinelibrary.wiley.com/doi/ abs/10.1111/j.1365-2494.1992.tb02251.x>. Accessed: Dec. 18, 2018. Doi: 10.1111/j.1365-2494.1992.tb02251.x.

LACA, E. A.; UNGAR, E. D.; DEMMENT, M. W. Mechanisms of handling time and intake rate of a large mammalian grazer. Applied Animal Behaviour Science, [S.L.], v.39, n.1, p.3-19, jan. 1994. Elsevier BV. Available from: <https:/www.sciencedirect. 
com/science/article/abs/pii/0168159194900116>. Accessed: Dec. 23, 2018. doi: 10.1016/0168-1591(94)90011-6.

LACA, E. A.; LEMAIRE, G. Measuring sward structure. Field and Laboratory Methods for Grassland and Animal Production Research, [S.L.], p.103-121, 2000. CABI. Accessed: Jan. 12, 2019. doi: 10.1079/9780851993515.0103.

MAURICIO, R. M., et al. A semi-automated in vitro gas production technique for ruminant feedstuff evaluation. Animal Feed Science and Technology, [S.L.], v.79, n.4, p.321-330, jun. 1999. Elsevier BV. Available from: <https://www.sciencedirect.com/science/ article/abs/pii/S0377840199000334>. Accessed: Feb. 15, 2019. doi: 10.1016/s0377-8401(99)00033-4.

MCNAUGHTON, S. J., and FF BANYIKWA. 1995. Plant communities and herbivory. In Serengeti II: Dynamics, management, and conservation of an ecosystem, ed. A.R.E. Sinclair and P. Arcese, 49-70 Chicago: University of Chicago Press.

MERTENS, D. R. Gravimetric determination of amylase-treated neutral detergent fiber in feed with refluxing in beakers or crucibles. pdf. AOAC international, v.85, n.November, p. 25, 2002.

MERTENS, D. R. 1994. Regulation of forage intake. In: FAHEY JR., G.C. (Ed.). Forage quality, evaluation and utilization. Winsconsin: American Society of Agronomy. p.450-493.

MOORE, J. E.; SOLLENBERGER, L. E. Techniques to predict pasture intake. In: SIMPÓSIO INTERNACIONAL SOBRE PRODUÇÃO ANIMAL EM PASTEJO, 1997, Viçosa. Anais... Viçosa, 1997. p.81-96. Available from: <https://animal.ifas.ufl. edu/apps/dairymedia/rns/2005/Coleman.pdf $>$. Accessed: Feb. $18,2019$.

PENNING, P. D.; RUTTER, S. M. Ingestive behavior. In: PENNING, P.D. (Ed.). Herbage intake handbook. 2.ed. Reading: The British Grassland Society, 2004.

PINTO, C. E. et al. Comportamento ingestivo de novilhos em pastagem nativa no Rio Grande do Sul. Revista Brasileira de Zootecnia, [S.L.], v.36, n.2, p.319-327, abr.2007. (SciELO). Available from: <https://www.scielo.br/scielo.php?pid=S1516$35982007000200007 \&$ script $=$ sci_abstract\&tlng=pt $>$. Accessed: Jan. 28, 2019. doi: 10.1590/s1516-35982007000200007.

POPPI, D. P.; HUGHES, T. P.; l'HUILLIER, P. J. Intake of pasture by grazing ruminants. In: NICOL, A.M. (Ed.). Livestock feeding on pasture. Hamilton: New Zealand Society of Animal Production, 1987, p.55-64. (Occasional Publication).

QUADROS, F. L. F. de; PILLAR, V. P..Dinâmica vegetacional em pastagem natural submetida a tratamentos de queima e pastejo. Ciência Rural, [S.L.], v.31, n.5, p.863-868, out. 2001. (SciELO). Available from: <https://www.scielo.br/scielo.php?pid=S0103$84782001000500020 \&$ script $=$ sci_abstract\&tlng $=\mathrm{pt}>$. Accessed: Mar. 10, 2019. doi: 10.1590/s0103-84782001000500020.

SANTOS, A. B et al. Nutritive value of Rio Grande do Sul/Brazil's native grasses, ranked according to functional typology under fire and grazing regimes. Ciência Rural, [online]. vol.43, n.2, pp.342347 fev 2013. Available from: <http://www.scielo.br/scielo. php? script $=$ sci arttext\&pid $=$ S0103-84782013000200025\&lng $=$ en $\& n r m=$ iso $>$. Accessed: Mar. 10, 2021. doi: 10.1590/S010384782013000200025 .
SCHOFIELD, P. Kinetics of fiber digestion from in vitro gas production. Journal of Animal Science, [S.L.], v.72, n.11, p.2980-2991, 1 nov. 1994. Oxford University Press (OUP). Available from: <https://academic.oup.com/jas/articleabstract/72/11/2980/4632581>. Accessed: mar 02, 2019. doi: 10.2527/1994.72112980x.

SILVEIRA, V. C. P. Pampa corte: um modelo de simulação para o crescimento e engorda de gado de corte. Ciência Rural, [S.L.], v.32, n.3, p.543-552, jun. 2002. (SciELO). Available from: <https://www.scielo.br/scielo.php?pid=S010384782002000300029\&script $=$ sci_abstract\&tlng=pt $>$. Accessed: Aug. 03, 2019. doi: 10.1590/s0103-84782002000300029.

STOBBS, T. The effect of plant structure on the intake of tropical pastures. I. Variation in the bite size of grazing cattle. Australian Journal of Agricultural Research, [S.L.], v. 24, n. 6, p. 809-819, 1973. CSIRO Publishing. Accessed: jul 16, 2019. Doi: 10.1071/ $\operatorname{ar9730809.~}$

THEODOROU, M. K. et al. James. A simple gas production method using a pressure transducer to determine the fermentation kinetics of ruminant feeds. Animal Feed Science and Technology, [S.L.], v.48, n.3-4, p.185-197, ago. 1994. Elsevier BV. Available from: <https://www.sciencedirect.com/science/ article/abs/pii/0377840194901716>. Accessed: Jul. 16, 2019. doi: 10.1016/0377-8401(94)90171-6.

TILMAN, D. et al. Productivity and sustainability influenced by biodiversity in grassland ecosystems. Nature, [S.L.], v.379, n.6567, p.718-720, fev. 1996. Springer Science and Business Media LLC. Available from: <https://www.nature. com/articles/379718a0>. Accessed: Oct. 24, 2018. doi: $10.1038 / 379718 \mathrm{a} 0$.

TRINDADE, J. P. P; ROCHA, M. G. Rebrotamento de capim caninha (Andropogon lateralis Nees) sob o efeito do fogo. Ciência Rural, [S.L.], v.31, n.6, p.1057-1061, dez. 2001. (SciELO). Available from: $<$ https://www.scielo.br/scielo.php?script=sci artt ext\&pid=S0103-84782001000600023 > . Accessed: Aug. 16, 2019. doi: $10.1590 / \mathrm{s} 0103-84782001000600023$.

TRINDADE, J. K. et al. Forage Allowance as a Target of Grazing Management: implications on grazing time and forage searching. Rangeland Ecology \& Management, [S.L.], v.65, n.4, p.382-393, jul. 2012. Elsevier BV. Available from: $<$ https://www.sciencedirect. com/science/article/abs/pii/S1550742412500631>. Accessed: Feb. 08, 2019. doi: 10.2111/rem-d-11-00204.1

TRINDADE, J. K. et al. Daily Forage Intake by Cattle on Natural Grassland: response to forage allowance and sward structure. Rangeland Ecology \& Management, [S.L.], v.69, n.1, p.59-67, jan. 2016. Elsevier BV. Available from: < https:// bioone.org/journals/Rangeland-Ecology-and-Management/ volume-69/issue-1/j.rama.2015.10.002/Daily-Forage-Intakeby-Cattle-on-Natural-Grassland--Response/10.1016/j. rama.2015.10.002.short>. Accessed: Jan. 23, 2019. doi: 10.1016/j.rama.2015.10.002.

UNGAR, E. D. Ingestive behaviour. In: HODGSON, J.; ILLIUS, A.W. The ecology and management of grazing systems. Oxon: CABI, 1996. p.185-218.

WILSON, W. J. Inclined point quadrats. New Phytol., v.59, n.1, p.1-8, 1960. 